\title{
Quantitative Characterization and Determination of the Main Factors That Control Fracture Development in the Lower Paleozoic Shale in Southeastern Chongqing, China
}

\author{
Zhiping Zhang, ${ }^{1,2}$ Xiangye Kong $\mathbb{D}^{\circ}{ }^{3}$ Qing Chen $\mathbb{D}^{4},{ }^{4}$ Ye Zhang, ${ }^{1,2}$ Zhi Deng, ${ }^{1,2}$ Chuan Yu, ${ }^{1}$ \\ Zhian Lei, ${ }^{5}$ Haijie Zhang, ${ }^{5}$ Xiaofeng Wang, ${ }^{6}$ Guanghua Yao, ${ }^{7}$ Licheng Yang, \\ and Xianfeng Tan $\mathbb{B D}^{4}$ \\ ${ }^{1}$ National and Local Joint Engineering Research Center of Shale Gas Exploration and Development, Chongqing Institute of Geology \\ and Mineral Resources, Chongqing 401120, China \\ ${ }^{2}$ Key Laboratory of Shale Gas Exploration, Ministry of Natural Resources, Chongqing Institute of Geology and Mineral Resources, \\ Chongqing 401120, China \\ ${ }^{3}$ State Key Laboratory of Petroleum Resources and Prospecting, China University of Petroleum, Beijing 102249, China \\ ${ }^{4}$ Chongqing Key Laboratory of Complex Oil and Gas Exploration and Development, Chongqing 401331, China \\ ${ }^{5}$ Chongqing Shale Gas Exploration and Development Company Limited, Chongqing 401121, China \\ ${ }^{6}$ Chongqing Institute of Geological Survey, Chongqing 401122, China \\ ${ }^{7}$ China Huaneng Group Co., Ltd. Chongqing Branch, Chongqing 401122, China \\ ${ }^{8}$ PetroChina Southwest Oil and Gasfield Company, Chongqing 401122, China
}

Correspondence should be addressed to Xiangye Kong; kongxiangyecup@163.com and Qing Chen; chenqing0144@126.com

Received 24 January 2021; Revised 9 April 2021; Accepted 19 April 2021; Published 6 May 2021

Academic Editor: Kun Zhang

Copyright ( 2021 Zhiping Zhang et al. This is an open access article distributed under the Creative Commons Attribution License, which permits unrestricted use, distribution, and reproduction in any medium, provided the original work is properly cited.

\footnotetext{
The Longmaxi and Niutitang Formations are typical shale reservoirs in southeastern Chongqing. Since the Paleozoic, southeastern Chongqing has experienced multistage tectonic movement and diagenesis, resulting in the formation of a large number of natural fractures. In shale reservoirs, fractures not only provide seepage channels for oil and gas migration but also play an important role in the oil and gas reservoir space. Natural fractures provide a flow path from source rock to reservoir during oil filling and connect hydraulic fractures, matrix pores, and boreholes during production. Therefore, identifying the main factors that control the development of natural fractures in the Longmaxi and Niutitang Formations in southeastern Chongqing has a guiding significance for the efficient development of shale reservoirs in this area. By considering the Longmaxi and Niutitang Formation shales as case studies, using field outcrops, drilling cores, and other data, and conducting X-ray diffraction (XRD) analysis as well as total organic carbon (TOC) measurements, the quantitative parameter characteristics and main factors that control the development of natural fractures in reservoir shales were examined in detail. The results obtained showed that there are three types of fractures in the lower Paleozoic shale in southeastern Chongqing, which are structural, diagenetic, and abnormal highpressure fractures. Among them, the fractures in the Longmaxi Formation shale, which are relatively abundant, predominantly consist of low-angle and high-angle inclined fractures, while the Niutitang Formation predominantly consists of high-angle fractures. Additionally, the investigation of fracture size and fracture density, as well as correlation analyses, showed that the fractures of the Lower Paleozoic shale are predominantly micro fractures that play a key role in improving reservoir seepage. It was also noted that the development of fractures is affected by several factors, including tectonic stress, mineral composition, organic carbon content, and rock thickness. The degree of fracture development was found to be positively correlated with brittle mineral and quartz contents, and high organic matter contents also significantly favored the formation micro fractures.
} 


\section{Introduction}

Since the 21st century, owing to a significant increase in the demand for energy, interest in unconventional oil and gas resources has increased significantly [1-6]. Natural fractures including structural fracture, diagenetic fracture, and abnormally high-pressure fracture are the dominant seepage channels for oil and gas filling and can connect hydraulic fractures and matrix holes with wellbores during the oil and gas production process $[7,8]$. Fractures are common in some shales, which may be the local factors affecting the growth of hydraulic fracture height [9]. Fractures are mainly concentrated in the shale with low clay content, and the abundance and size of outcrop fractures vary greatly [9]. In the subsurface, shales may consist of complex, stratified fractured, and nonfractured rocks [9]. Therefore, to evaluate the distribution of shale oil and gas sweet spots, it is necessary to study the development of natural fractures [10-12]. This is of great significance and may help to minimize drilling and completion costs.

Sichuan-Chongqing area is the key target for shale gas exploration and development in China $[13,14]$. The southeastern Chongqing has experienced the superimposed transformation of multistage tectonic activities, which have made its stratigraphic relationships and structural characteristics more complex $[15,16]$, and simultaneously, it consists of a large number of natural structural fractures. Complex diagenesis, hydrocarbon generation, and expulsion have also had an important impact on the opening of bedding fractures in this area $[17,18]$. These natural fractures are one of the important factors responsible for the differences in the oil and gas properties of shale reservoirs in southeastern Chongqing. Previous studies on shale oil and gas in southeastern Chongqing have been primarily focused on regional structure, reservoir lithology, pore structure, and sedimentary characteristics $[19,20]$. The reservoir properties of the Longmaxi Formation in this region are rich and have the greatest potential for gas production because of total organic carbon (TOC) enrichment, higher thermal maturity, and improved fracture potential [20]. There are several stages of hydrocarbon generation, migration, and accumulation in this formation [19]. However, research on natural fractures is relatively scarce, and the main factors that control their development are still unclear; this limits the efficient development of tight oil in the study area. In this regard, by using field outcrops, drilling cores, and other data and conducting $\mathrm{X}$-ray diffraction (XRD) analysis as well as TOC measurements, this study focuses on the main factors that control shale fracture development in the Longmaxi and Niutitang Formations in southeastern Chongqing, to provide a new reference for marine shale gas exploration, prediction, and optimization in South China.

\section{Geological Setting}

Southeastern Chongqing is located in the upper Yangtze platform and belongs to the East Sichuan fold belt in the southeast of the Sichuan Basin $[21,22]$. The west of this area is bounded by the Huayingshan deep fault, which is connected to the central Sichuan structural area. The eastern part is bounded by the Qiyue fault and is adjacent to the fault fold belt in Western Hubei [21]. From southeast to northwest are the Shizhu syncline, Fangdoushan anticline, and Wanxian syncline [23] (Figure 1). The inner part of the fault fold belt in which the anticline is narrow and the stratum is steep and tight, is predominantly linear, with an inverted wing. Usually, two wings lie asymmetrically, and thrust faults are often developed in the core part. Additionally, the syncline axis is wide and the stratum is gentle.

In southeastern Chongqing, there are no upper Silurian and Devonian strata. Almost all the strata are Carboniferous. In some areas, there are Middle Triassic Series, and in most areas, there are Jurassic, Cretaceous, Paleogene, and Neogene strata. Additionally, the Paleozoic strata are mainly exposed $[24,25]$. On the surface of the Jiaoshiba structure, only the Huanglong Formation of the Carboniferous system is preserved, while the Devonian system is absent. Other marine strata are relatively intact. The Niutitang Formation of the Lower Cambrian disagrees with the Dengying Formation, with gray green shale or black carbonaceous shale at the bottom and siliceous rock intercalated with carbonaceous shale at the upper part [25-28]. The Longmaxi Formation of the Lower Silurian system is composed of black shale, silty shale, and light gray and yellow siltstone, which are high-quality shale intervals for shale gas exploration and development.

\section{Data and Methods}

The identification and observation of outcrop fractures mainly included three observation points (Pengshui, Youyang, and Xiushan) and six cores (Yuancan-9, Xiuye-6, Youdi-2, Youye-1, Xiuqian-1, and Youcan-1). Parameters, such as fracture strike and dip, were measured using a compass, and parameters, such as fracture length and opening, were directly measured using a meter rule. A total of 1486 pairs of fracture occurrence data points were sampled. Simultaneously, the TOC contents of 17 shale samples from Well Yucan-7 were determined using a Leco CS-230 carbon at the Sichuan Coalfield Geology Bureau, and the XRD patterns of 41 shale samples from Well Yucan-8 were determined using Bruker D8 Advance at the State Key Laboratory of Oil and Gas Reservoir Geology and Exploitation (Chengdu University of Technology, China) under temperature and humidity conditions of $25^{\circ} \mathrm{C}$ and $50 \%$, respectively.

\section{Results}

\subsection{Fracture Types and Development Characteristics}

4.1.1. Structural Fracture. This type of structure refers to the fracture caused by regional or local tectonic stress, which is mainly controlled by in situ stress and is closely related to fracture tectonic deformation. The structural fractures in the Longmaxi and Niutitang Formations in southeastern Chongqing, which are mainly vertical or high-angle structures, are the most developed in the field outcrop. It was observed that the regional structural joint surfaces are straight, penetrating deep and extending long, perpendicularly to the surface layer, or intersecting with the 


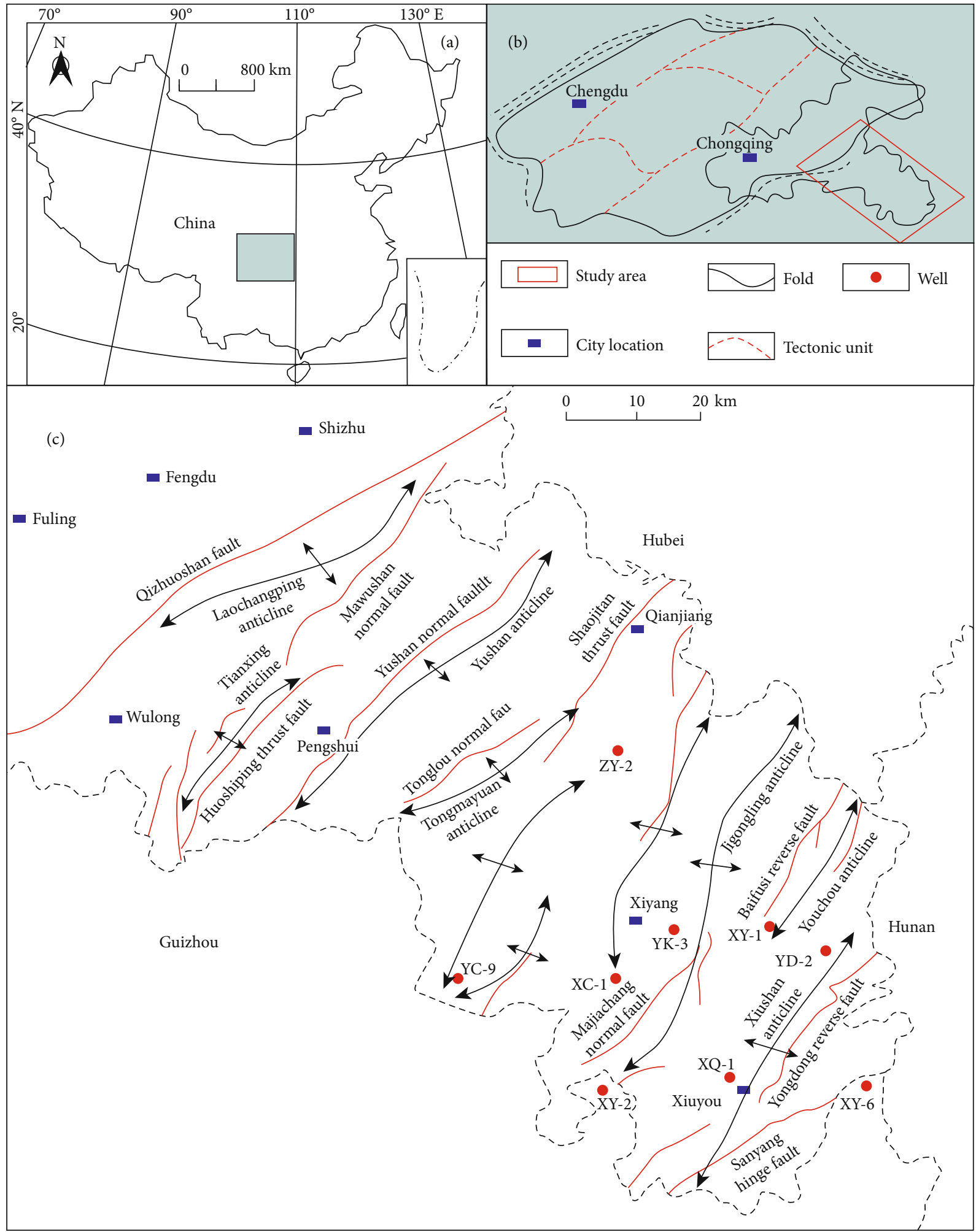

FIGURE 1: Distribution map of folds and fault systems in the target layer of southeastern Chongqing.

rock surface at a large angle [29-32]. The high-angle shear fractures on the outcrop are characterized by multistage fractures cutting each other in the plane, extending long in the longitudinal direction, and often cutting through the rock strata. Additionally, the same group of fractures showed good equidistance (Figure 2(a)). According to the relationship between fractures and shale layers, mainly two types of shear fractures exist in the Longmaxi and Niutitang Formations in southeastern Chongqing, the high-angle through layer fractures, which are approximately perpendicular to 


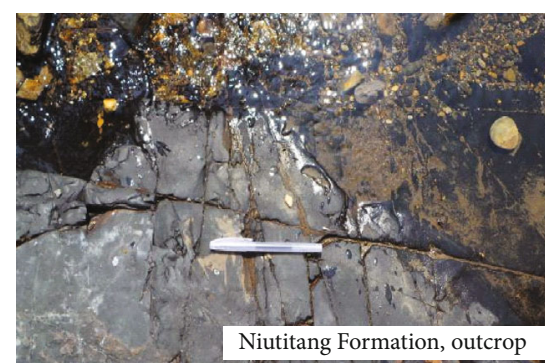

(a)

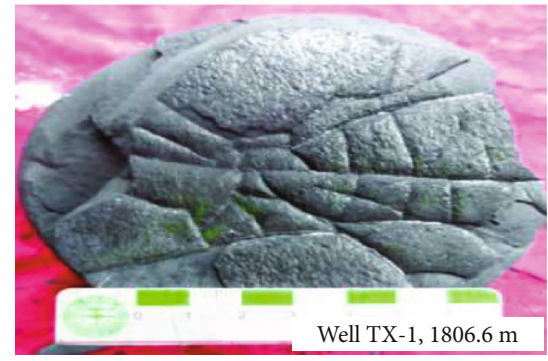

(d)

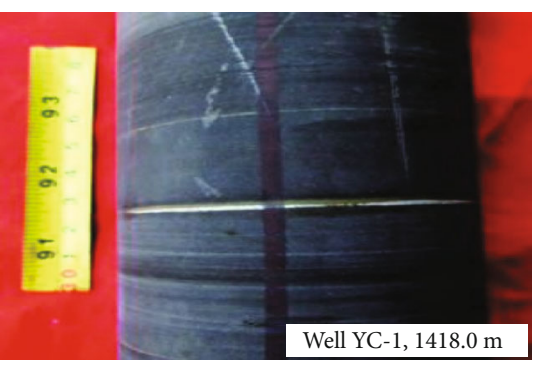

(g)

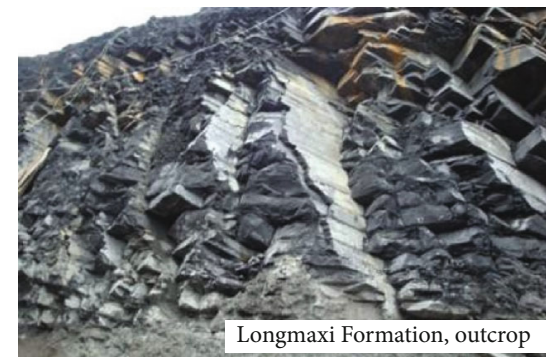

(b)

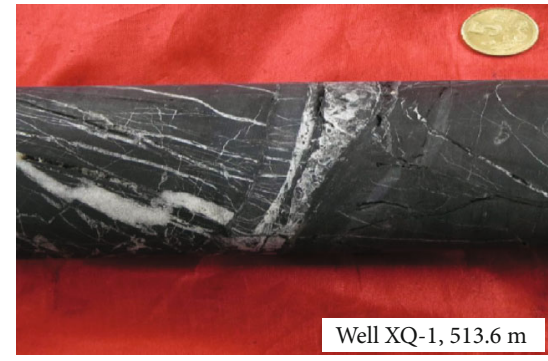

(e)

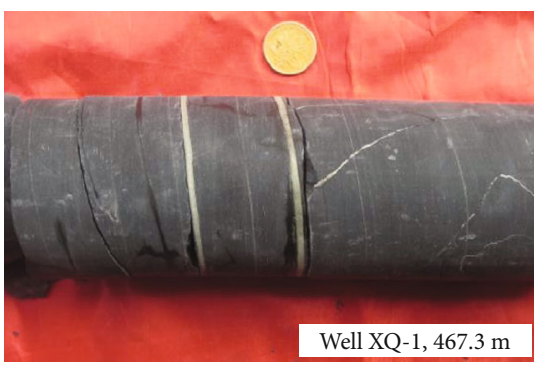

(h)

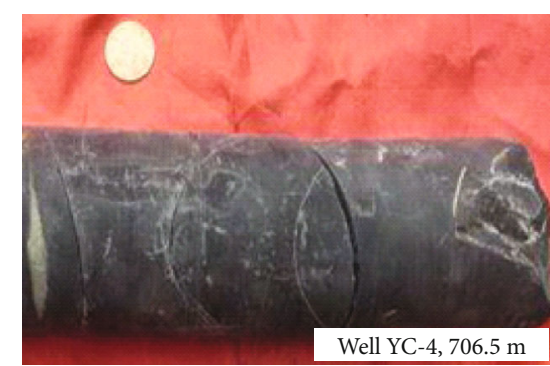

(c)

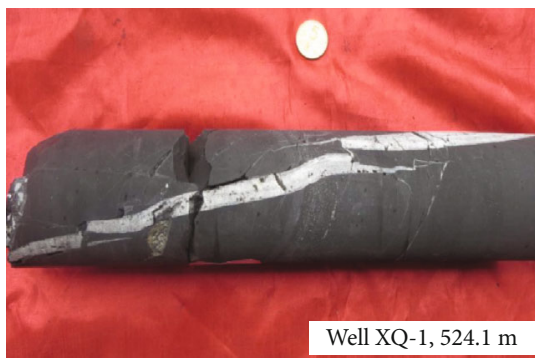

(f)

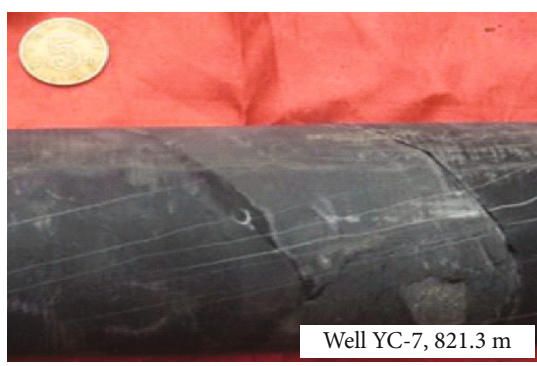

(i)

FIGURE 2: Shale fracture development characteristics in the target layer of southeastern Chongqing.

the bedding plane, and the low-angle slip fractures, which are approximately parallel to the bedding plane or the tensile fractures formed by the locally derived tensile stress under the compressive stress environment.

It was observed that the high-angle shear fractures on the core have straight fracture surfaces, small fracture spacings, and high fracture development degrees, and the same group of fractures showed similar spacings, and the fractures of different groups cut each other. The openings of high-angle shear fractures, which are often filled with quartz, calcite, pyrite, and other minerals, changed significantly, and the other fractures showed smaller openings and higher filling degrees (Figures 2(d) and 2(c)).

The fracture surface of the low-angle slippage fracture is not smooth and is often filled with quartz, calcite, and other minerals (Figure 2(e)), and on the fracture surface, there are scratches and steps. Additionally, the developed tension fractures in the target layer in the study area were mainly formed under the influence of the compression background and sometimes appeared simultaneously with the conjugate shear fractures. Tension fractures are mainly distributed above the neutral fold planes, and most of them are located in the hinge area. In the Niutitang Formation shale in southeastern Chongqing, the degree of opening of the fractures, which changes significantly, is large. Additionally, it was observed that the fracture surface, which is often filled with quartz, calcite, and other minerals and has a short fracture extension length (Figure 2(f)), is not straight.

4.1.2. Diagenetic Fracture. This type of structure is defined as a dilatational or tensile fracture with a decrease in the total volume of the rock. Diagenetic fractures are a type of nearhorizontal fractures caused by pressure solution, compaction, and pressure release [33-35]. These fractures, which are developed in the outcrop shale of the Longmaxi Formation, are predominantly horizontal foliation fractures and bedding slip joints. The bedding structure of shale with foliate or lamellar bedding is the weakest mechanical structural plane, and its antiweathering ability is weak. Owing to weathering, leaching, and denudation for a long time, it is easily peeled off or it slides along the bedding plane and the existing fracture surface, forming a large number of bedding joints and layer slip joints (Figure 2(b)). The Lower Paleozoic shales are usually composed of a series of thin shales formed under strong hydrodynamic conditions. Mechanical compaction and water loss shrinkage bring about the shale fracture along the foliation, forming foliation fractures (Figures 2(g) and 2(h)). 


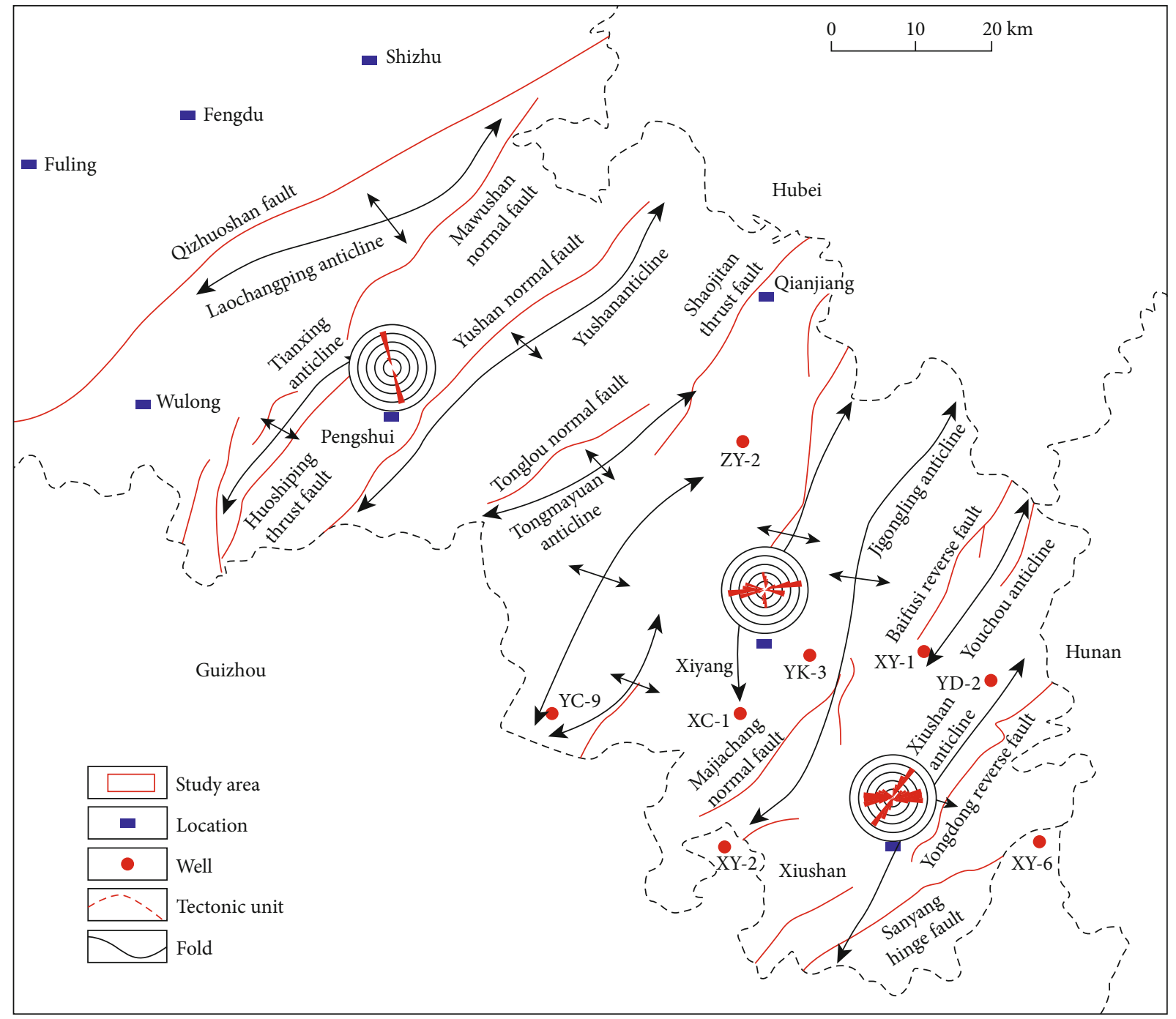

FIGURE 3: Strike rose diagrams of black shale fractures in the target layer of southeastern Chongqing.

4.1.3. Abnormally High-Pressure Fractures. Abnormal highpressure fractures are mainly drainage fractures, which are converted from a principal stress to tensile stress under the action of extremely high fluid pressure, resulting in fracture clusters with bending directions and different openings. Abnormally high shale pressures primarily result from three aspects: (1) the abnormal gas pressure formed in the process of organic matter evolution, which is related to organic matter content and is controlled by the thermal evolution degree of organic matter [36, 37]; (2) the black thick-layered organic matter-rich shale, which is under compaction due to rapid sedimentation [38]; or (3) the closed state, within which an abnormally high fluid pressure is generated owing to the combination of the dehydration and hydrothermal pressurization of clay minerals. When the abnormally high fluid pressure exceeds the rock fracture strength, fractures are formed. Abnormally high-pressure fractures are usually distributed in areas with relatively high organic matter content, where the maturity of the organic matter is also relatively high. These fractures are characterized by an irregular shape, a short extension, and their occurrence varies significantly (Figure 2(i)).

\subsection{Characterization of Fracture Parameters}

4.2.1. System and Occurrence of Fracture. According to the rose diagram of the fracture strike corresponding to the target layer in the survey area, there are mainly three stages of structural fractures in southeastern Chongqing. These are the near EW, NE (strike $\mathrm{N} 30^{\circ} \mathrm{E}$ ), and near SN directions (Figure 3). The plane-cutting relationship of the fractures on the outcrop shows that a group of structural fractures in the near SN direction limit the two groups of fractures to the near EW and NE directions, indicating that the group of structural fractures close to the near SN direction was formed first. Simultaneously, a group of structural fractures in the near EW direction limit the expansion of a group of structural fractures in the NE direction, indicating that the group of fractures in the near EW direction formed earlier than the group of fractures in the NE 


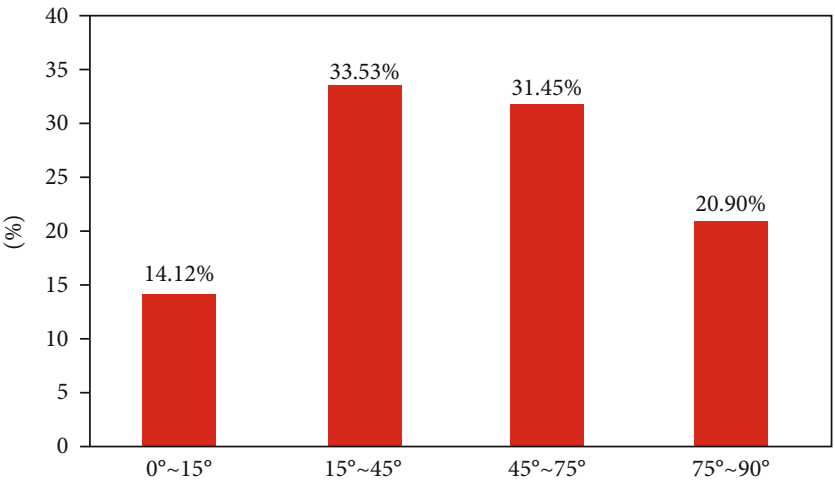

(a)

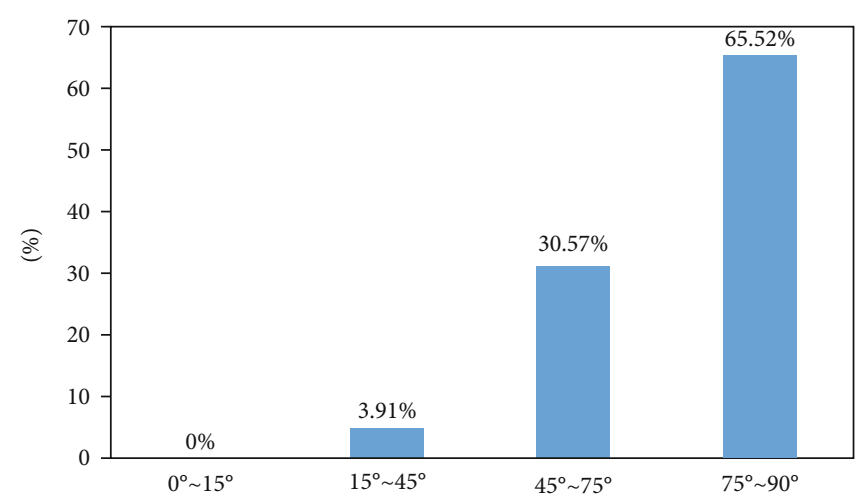

(b)

FIgURE 4: Distribution frequency diagram of shale fracture dip angle in the target layer, i.e., Longmaxi Formation (a) and Niutitang Formation (b), of southeastern Chongqing.

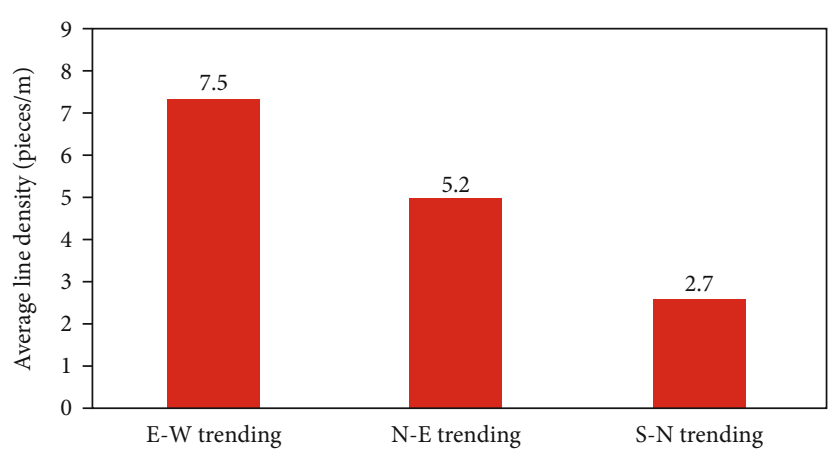

(a)

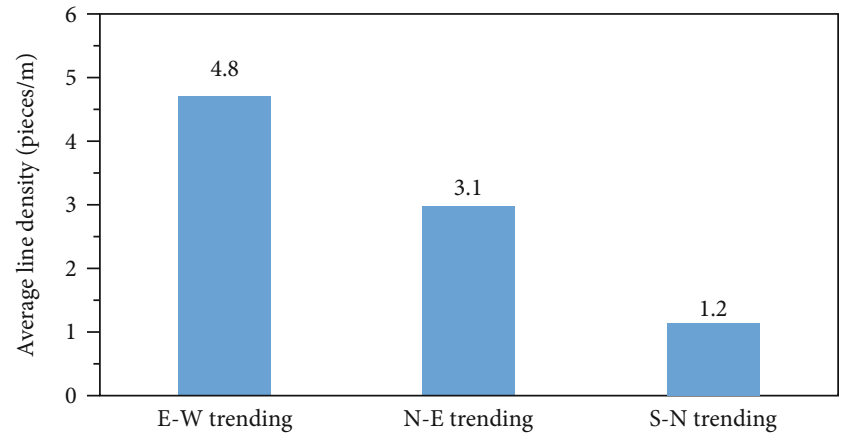

(b)

FiguRE 5: Shale fracture density distribution map in the target layer, i.e., Longmaxi Formation (a) and Niutitang Formation (b), of southeastern Chongqing.

direction; i.e., the fractures trending in the NE direction were formed last. In the Youyang survey area, structural fractures in the near EW and near SN directions showed distinct development advantages, while in the Xiushan survey area, those in the near EW and NE directions showed distinct development advantages (Figure 3).

According to the statistical results obtained following the measurement of the fracture dip angles in the study area, most of the fractures in the Longmaxi Formation shale are predominantly inclined with low angles $\left(15^{\circ}-45^{\circ}\right)$ and high angles $\left(45^{\circ}-75^{\circ}\right)$, and only a few are vertical and horizontal (i.e., inclined at $75^{\circ}-90^{\circ}$ and $0^{\circ}-15^{\circ}$, respectively). It was observed that $20.90,31.45,33.53$, and $14.12 \%$ of these fractures are inclined at angles in the ranges $75^{\circ}-90^{\circ}, 45^{\circ}-75^{\circ}$, $15^{\circ}-45^{\circ}$, and $0^{\circ}-15^{\circ}$, respectively, as shown in Figure 4(a). It was also observed that vertical fractures, high-angle cutting fractures, and low-angle oblique fractures are developed in the Niutitang Formation shale, while horizontal fractures are rare. Among these fractures, 65.52 and $49.4 \%$ (approximately half of the total) are inclined at angles in the ranges $75^{\circ}-90^{\circ}$ and $>81^{\circ}$, respectively. Additionally, a total of 30.57 and $3.9 \%$ of these fractures are inclined at angles in the ranges $45^{\circ}-75^{\circ}$ and $15^{\circ}-45^{\circ}$, respectively, while horizontal fractures $\left(0^{\circ}-15^{\circ}\right)$ are absent. These results show that the shale fractures of the Niutitang Formation are mainly highangle fractures, followed by oblique fractures, and lowangle fractures, while horizontal fractures are not developed (Figure 4(b)).

4.2.2. Fracture Density. The calculation method of fracture density can been seen previous study in detail [39]. It was observed that the fracture densities corresponding to the three dominant directions of the target layer in the study area are different. The average linear density of the fractures, i.e., the number of fractures in per unit area, in the near SN, NE, and near EW directions in the Longmaxi Formation is approximately 2.7, 5.2, and 7.5 pieces $/ \mathrm{m}$, respectively (Figure 5(a)). For the Niutitang Formation, they are approximately 1.2, 3.1, and 4.8 pieces $/ \mathrm{m}$, respectively (Figure 5(b)). This finding indicates that the fractures in the shale of the target layer in southeastern Chongqing are mainly NE and near EW fractures, with the most developed and least developed being the near EW and near SN fractures, respectively. Moreover, the Longmaxi Formation was found to be better than the Niutitang Formation. The two sets of shale fractures in southern Chongqing, which are more significant in terms of shale gas enrichment and development, are greater in number than those in conventional sandstone reservoirs. 


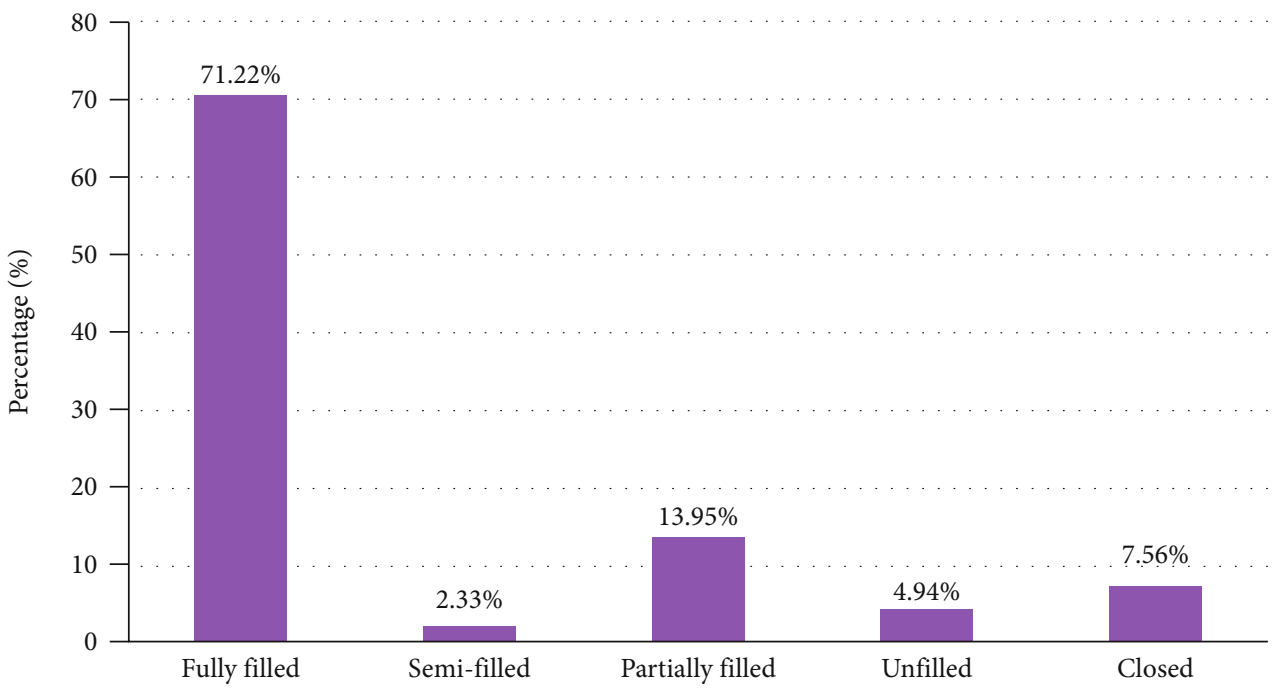

(a)

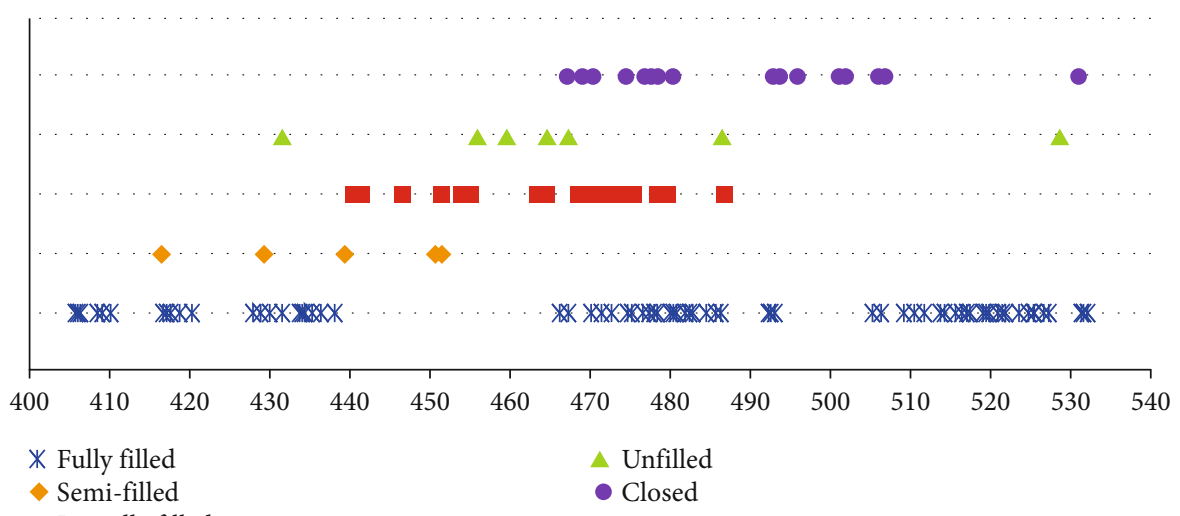

(b)

FIGURE 6: Statistics of fracture filling in the target layer of southeastern Chongqing.

4.2.3. Fracture Filling. The fracture surface morphologies of approximately $160 \mathrm{~m}$ long cores from Well Yucan-8 in the Longmaxi Formation and Well Xiuqian-1 in the Niutitang Formation were observed and described in detail. Overall, it was observed that more than $87 \%$ of the fractures are filled, approximately $5 \%$ are unfilled, and approximately $8 \%$ are closed. Most of the filling joints are fully filled, while a few are partially filled or semifilled (Figure 6(a)). The filling mineral is mainly calcite, and occasionally, it is pyrite (Figure 6(b)). Vertically, taking Well Xiuqian-1 as an example, the length of the observed core was found to be approximately $130 \mathrm{~m}$, and it was observed that the fully filled fractures are generally developed in other depth sections except for the well section at a depth range of 440-460 m. Some of the filled fractures were mainly observed in the well section at a depth range of 440-480 m. The unfilled fractures were found to be concentrated within a depth range of 455$465 \mathrm{~m}$, and the closed fractures were observed at two well depth ranges of 460-480 and 490-505 m. Additionally, semifilled fractures were scattered at depths of 415, 429, 439, and $450 \mathrm{~m}$ (Figure 7). Overall, the shale fracture filling degree corresponding to Well Xiuqian-1 in the Niutitang Formation, which has adverse effects on shale gas reservoirs and seepage, is relatively high.

\section{Discussion}

The shale reservoirs of the Longmaxi and Niutitang Formations in southeastern Chongqing have strong heterogeneity, and the degree of fracture development in the different regions of the study area is very different $[40,41]$. Based on mineral composition, TOC content, and layer thickness, the factors that influence shale fracture development in the Longmaxi and Niutitang Formations in southeastern Chongqing were comprehensively studied.

5.1. Mineral Composition. Mineral composition can affect the degree of the fracture development; i.e., both carbonates and quartz contribute to the increase of crack density. According to the results of the XRD analysis of the 789-860 m section of Well Yucan-8, the brittle mineral in this section is predominantly quartz, and based on quartz content and fracture statistics data, the relationship between fracture development in Well Yucan-8 in the Longmaxi Formation shale and quartz 


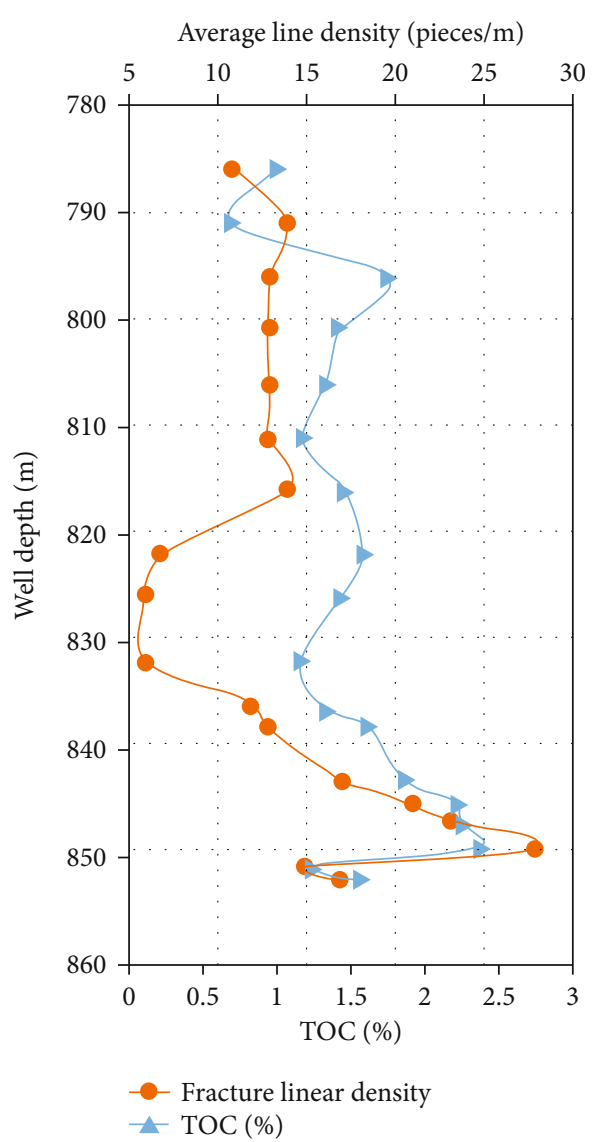

FIgURE 7: Relationship between TOC and shale fracture development in Well Yucan-7 of the Longmaxi Formation in southeastern Chongqing.

content was obtained (Figure 8). Thus, it is observed that there is a certain degree of positive correlation between quartz content and fracture linear density; i.e., the higher the quartz content, the greater the fracture linear density.

5.2. Organic Matter Content. The influence of TOC on fracture development is mainly reflected by the distribution of organic matter [32], the consumption of organic components and water for kerogen hydrocarbon generation, and hydrocarbon generation pressurization. The higher the organic matter content, the more obvious the banding and the easier it is for micro fractures to develop in or around the organic matter band. According to the statistical results corresponding to the relationship between organic carbon content and the degree of shale gas development in various regions of the world, the higher the organic carbon content, the greater the number of micro pores in the shale matrix, and the greater the number of micro fractures formed, the higher the number of shale gas reservoirs [32].

Based on statistics corresponding to the fracture linear density and TOC of Well Yucan-7 in the study area (Figure 7), the organic matter content in the 786-836 m well section is below $1.6 \%$ and has little influence on fracture density and the fracture development. Additionally, low TOC contents, which showed no obvious change trend, were

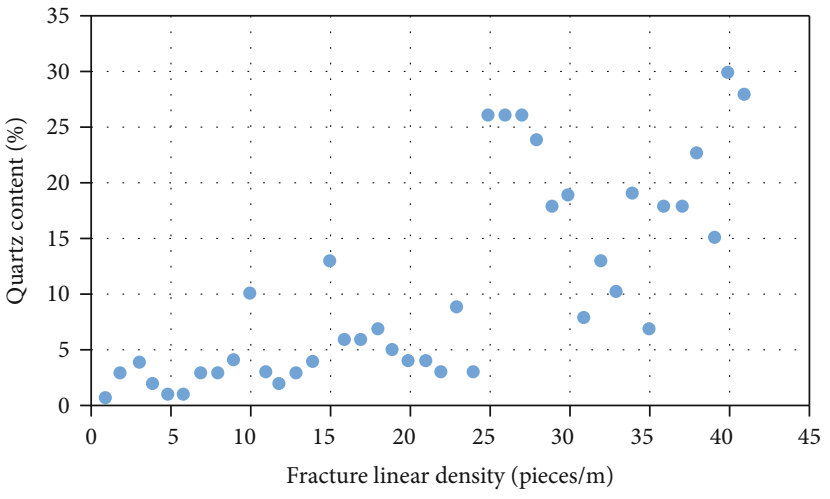

Figure 8: Relationship between shale fracture development and quartz content in Well Yucan-8 of the Longmaxi Formation in southeastern Chongqing.

observed. However, within the $838-849 \mathrm{~m}$ well section, TOC and fracture density showed a distinct correlation. It was observed that changes in organic matter contents in the range 1.6-2.5\% have a significant effect on fracture density. Specifically, when TOC changes from 1.63 to $2.38 \%$, the fracture linear density increases from 13 to 28 pieces $/ \mathrm{m}$.

This is primarily due to the high sea level that characterized the beginning of the shale deposition. Nutrient-rich upwelling carried the remains of animals and plants from the deep sea, making the biological yield high and forming the still water deep slope basin facies with a strong reduction environment. It was observed that the organic matter is well preserved and is enriched. The sediments primarily consisted of semipelagic ooze (from shallow water shelf) and biological skeleton debris. Siliceous organisms, such as radiolarians, were found to be buried, an observation that is closely related to the high organic matter content. However, marine organic matter-rich shales with high organic carbon contents and high silicon contents are prone to fracture. Thus, a positive correlation was observed between organic carbon content and shale fracture development. For the Longmaxi Formation shale, at TOC values $<1.6 \%$, the relationship between the fracture development degree and organic carbon content is not distinct. However, when TOC ranges between 1.6 and $2.5 \%$, the relationship between the fracture development degree and organic carbon content is distinct. Thus, the overall change trend is consistent, and the degree of fracture development is good.

5.3. Formation Thickness. Generally, thin-layer rocks are more prone to fracturing than their thicker counterparts, and fracture spacing is positively correlated with the thickness of the formation [42]. Previous studies have shown that the smaller the stratum thickness, the higher the degree of fracture development under the same geomechanical environment. According to statistics corresponding to fracture development in Well Yushen-l in the Longmaxi Formation shale, the fracture development degree is negatively correlated with formation thickness; i.e., the degree of fracture development decreases as the formation thickness increases (Figure 9). 


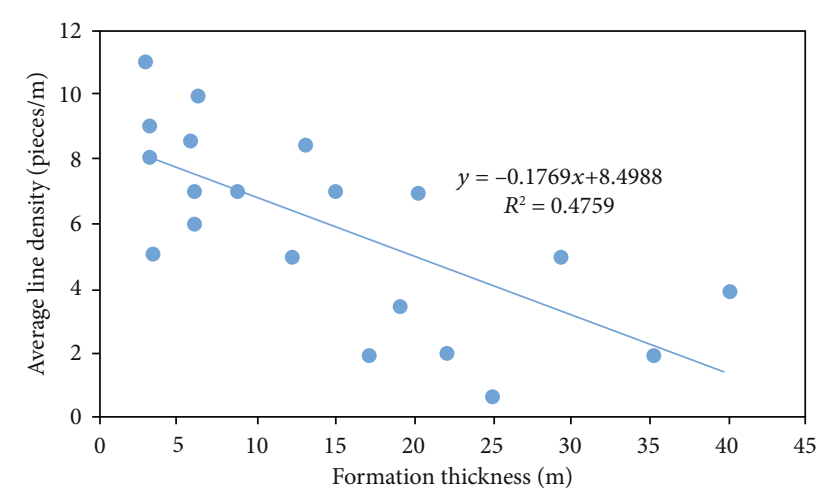

FIgURE 9: Relationship between shale fracture development and stratum thickness in the Longmaxi Formation in Yushenjing District, southeastern Chongqing.

\section{Conclusions}

The fractures in the Longmaxi and Niutitang Formation shales can be divided into structural, diagenetic, and abnormal high-pressure fractures. Additionally, the structural fractures can be further divided into tensile and shear fractures depending on their mechanical properties. The shear fractures can be classified as high-angle through layer fractures and low-angle slip fractures based on their relationship with the shale layers. However, diagenetic fractures can be divided into horizontal foliation fractures, bedding plane slip joints, and high-angle shrinkage fractures depending on their relationship with the shale layers.

The fractures in the Longmaxi Formation shale in southeastern Chongqing are predominantly low-angle and high-angle inclined fractures that are partially vertical or horizontal. In the Niutitang Formation shale, they are predominantly high-angle fractures, followed by oblique fractures, and a few low-angle fractures, with horizontal fractures absent.

Furthermore, it was also observed that the fractures in the Longmaxi and Niutitang Formations in southeastern Chongqing are predominantly micro fractures with small fracture openings. The underground opening of shale reservoirs restored to underground confining pressure is mainly in the range $0-350 \mu \mathrm{m}$. Compared with shale matrix pores, it was observed that the reservoir effect of fractures is relatively small and primarily improves the seepage of ultralowpermeability reservoirs. Additionally, high-angle macro structural fractures are the main seepage fractures of the target layer.

The results obtained showed that the degree of fracture development is positively correlated with the brittle mineral and organic carbon content of the rocks. Additionally, higher quartz contents resulted in a greater fracture linear density, and higher organic carbon contents resulted in an increase in the number of the micro pores and micro fractures formed in the shale matrix. Besides, the fracture development degree is negatively correlated with formation thickness; i.e., the degree of fracture development decreases as the formation thickness increases.

\section{Data Availability}

The main data used to support the study is available within the article. If readers are interested in the data, they can communicate with the corresponding author and obtain these data by email.

\section{Conflicts of Interest}

The authors declare that they have no conflicts of interest.

\section{Acknowledgments}

We greatly thank all the teachers in Chongqing University of Science and Technology for the analysis and guidance of experimental samples. This work was financially supported by the National Natural Science Foundation of China (Grant Numbers 42072140 and 41502150), Natural Science Foundation Project of Chongqing, Chongqing Science and Technology Commission (CQ CSTC) (Grant Numbers cstc2018jcyjAX0523 and cstc2020jcyj), the Performance Incentive and Guidance Project for Scientific Research Institutions in Chongqing (Grant Number cstc2020jxjlX0002), Special Project of performance incentive and guidance for scientific research institutions in Chongqing (Grant Number cstc2019jxj190001), and the Preproject of Chongqing Shale Gas Exploration and Development Company Limited (Grant Number CYS-FW-2020-0047). We thank our scientific research team for their help and guidance in the field investigation.

\section{References}

[1] B. E. Law and J. B. Curtis, "Introduction to unconventional petroleum systems," American Association of Petroleum Geologists Bulletin, vol. 86, no. 11, pp. 1851-1852, 2002.

[2] X. Wang, J. Hou, S. Li et al., "Insight into the nanoscale pore structure of organic-rich shales in the Bakken Formation, USA," Journal of Petroleum Science and Engineering, vol. 191, p. 107182, 2020.

[3] C. Zou, Z. Yang, S. Tao et al., "Continuous hydrocarbon accumulation over a large area as a distinguishing characteristic of unconventional petroleum: the Ordos Basin, North-Central China," Earth-Science Reviews, vol. 126, pp. 358-369, 2013.

[4] C. Zou, Z. Yang, J. Dai et al., "The characteristics and significance of conventional and unconventional Sinian-Silurian gas systems in the Sichuan Basin, central China," Marine and Petroleum Geology, vol. 64, pp. 386-402, 2015.

[5] J. Qiao, R. Littke, L. Zieger, Z. Jiang, and R. Fink, "Controls on gas storage characteristics of Upper Paleozoic shales from the southeastern Ordos Basin," Marine and Petroleum Geology, vol. 117, article 104377, 2020.

[6] J. Qiao, A. Baniasad, L. Zieger, C. Zhang, Q. Luo, and R. Littke, "Paleo-depositional environment, origin and characteristics of organic matter of the Triassic Chang 7 Member of the Yanchang Formation throughout the mid- western part of the Ordos Basin, China," International Journal of Coal Geology, vol. 237, article 103636, 2021.

[7] J. F. W. Gale, R. M. Reed, and J. Holder, "Natural fractures in the Barnett Shale and their importance for hydraulic fracture treatments," AAPG Bulletin, vol. 91, no. 4, pp. 603-622, 2007. 
[8] Y. Cho, O. G. Apaydin, and E. Ozkan, "Pressure-dependent natural-fracture permeability in shale and its effect on shalegas well production," SPE Reservoir Evaluation \& Engineering, vol. 16, no. 2, pp. 216-228, 2013.

[9] J. F. Gale, S. E. Laubach, J. E. Olson, P. Eichhubl, and A. Fall, "Natural fractures in shale: a review and new observations," AAPG Bulletin, vol. 98, no. 11, pp. 2165-2216, 2014.

[10] S. Zhang, "Tectonic stress field modeling and fracture prediction in T3x (2-4) strata in Xiaoquan-Xinchang area, western Sichuan depression," Oil \& Gas Geology, vol. 25, no. 1, pp. 70-74, 2004.

[11] W. Zeng, W. Ding, J. Zhang et al., "Fracture development in Paleozoic shale of Chongqing area (South China). Part two: numerical simulation of tectonic stress field and prediction of fractures distribution," Journal of Asian Earth Sciences, vol. 75, pp. 267-279, 2013.

[12] K. Jiu, W. Ding, and Y. Li, "Structural features in northern Guizhou area and reservoir fracture of lower Cambrian shale gas," Natural Gas Geoscience, vol. 23, no. 4, pp. 797-803, 2012.

[13] R. Wang, W. Ding, Y. Zhang et al., "Analysis of developmental characteristics and dominant factors of fractures in Lower Cambrian marine shale reservoirs: a case study of Niutitang formation in Cen'gong block, southern China," Journal of Petroleum Science and Engineering, vol. 138, pp. 31-49, 2016.

[14] R. Wang, Z. Hu, C. Sun et al., "Comparative analysis of shale reservoir characteristics in the Wufeng-Longmaxi (O3w-S1l) and Niutitang $(€ 1 n)$ formations: a case study of the Wells JY1 and TX1 in southeastern Sichuan Basin and its periphery, SW China," Interpretation, vol. 6, no. 4, pp. SN31-SN45, 2018.

[15] Y. Li, W. Sun, X. W. Liu, D. W. Zhang, Y. C. Wang, and Z. Y. Liu, "Study of the relationship between fractures and highly productive shale gas zones, Longmaxi Formation, Jiaoshiba area in eastern Sichuan," Petroleum Science, vol. 15, no. 3, pp. 498-509, 2018.

[16] S. Han, J. Zhang, C. Wang, and X. Tang, "Elemental geochemistry of lower Silurian Longmaxi shale in southeast Sichuan Basin, South China: Constraints for Paleoenvironment," Geological Journal, vol. 53, no. 4, pp. 1458-1464, 2018.

[17] C. Ou and C. Li, "3D discrete network modeling of shale bedding fractures based on lithofacies characterization," Petroleum Exploration and Development, vol. 44, no. 2, pp. 336345, 2017.

[18] C. Peng, "Mechanism of interaction between hydraulic fractures and weak plane in layered shale," Petroleum Drilling Techniques, vol. 84, no. 3, pp. 181-196, 2014.

[19] T. Guo and H. Zhang, "Formation and enrichment mode of Jiaoshiba shale gas field, Sichuan Basin," Petroleum Exploration and Development, vol. 41, no. 1, pp. 31-40, 2014.

[20] S. Chen, Y. Zhu, H. Wang, H. Liu, W. Wei, and J. Fang, "Shale gas reservoir characterisation: a typical case in the southern Sichuan Basin of China," Energy, vol. 36, no. 11, pp. 66096616, 2011.

[21] K. Zhang, C. Jia, Y. Song et al., "Analysis of Lower Cambrian shale gas composition, source and accumulation pattern in different tectonic backgrounds: a case study of Weiyuan block in the upper Yangtze region and Xiuwu Basin in the Lower Yangtze region," Fuel, vol. 263, article 115978, 2020.

[22] K. Zhang, J. Peng, W. Liu et al., "The role of deep geofluids in the enrichment of sedimentary organic matter: a case study of the Late Ordovician-Early Silurian in the upper Yangtze region and early Cambrian in the lower Yangtze region, south China," Geofluids, vol. 2020, Article ID 8868638, 12 pages, 2020.

[23] Y. Zhang, S. Dong, J. Li, and W. Shi, "Mesozoic multidirectional compressional tectonics and formationreformation of Sichuan Basin," Geology in China, vol. 38, no. 2, pp. 233-250, 2011.

[24] K. Zhang, J. Peng, X. Wang et al., "Effect of organic maturity on shale gas genesis and pores development: a case study on marine shale in the upper Yangtze region, South China," Open Geosciences, vol. 12, no. 1, pp. 1617-1629, 2020.

[25] Y. Wang, D. Dong, X. Li, J. Huang, S. Wang, and W. Wu, "Stratigraphic sequence and sedimentary characteristics of Lower Silurian Longmaxi Formation in Sichuan Basin and its peripheral areas," Natural Gas Industry B, vol. 2, no. 2-3, pp. 222-232, 2015.

[26] Q. Li, S. Shao, and X. Xia, "Characterization and geological model of fractured shale reservoir in eastern China," Egu General Assembly, vol. 14, p. 6672, 2012.

[27] W. Li, H. Yu, and H. Deng, "Stratigraphic division and correlation and sedimentary characteristics of the Cambrian in central-southern Sichuan Basin," Petroleum Exploration and Development, vol. 39, no. 6, pp. 725-735, 2012.

[28] L. Wei, R. Fan, P. Jia et al., "Sequence stratigraphy and lithofacies paleogeography of the Middle-Upper Cambrian Xixiangchi Group in the Sichuan Basin and its adjacent area, SW China," Petroleum Exploration and Development, vol. 46, no. 2, pp. 238-252, 2019.

[29] B. Marc-André, M. Yan, and D. Stead, "The role of tectonic damage and brittle rock fracture in the development of large rock slope failures," Geomorphology, vol. 103, no. 1, pp. 3049, 2009.

[30] Z. Ji, J. Dai, B. Wang, and H. Liu, "Multi-parameter quantitative calculation model for tectonic fracture," Journal of China University of Petroleum (Edition of Natural Ence), vol. 34, no. 1, pp. 24-28, 2010.

[31] L. Rivera and H. Kanamori, "Spatial heterogeneity of tectonic stress and friction in the crust," Geophysical Research Letters, vol. 29, no. 6, pp. 12-1-12-4, 2002.

[32] W. Zeng, J. Zhang, W. Ding et al., "Fracture development in paleozoic shale of Chongqing area (South China). Part one: fracture characteristics and comparative analysis of main controlling factors," Journal of Asian Earth Sciences, vol. 75, no. 5, pp. 251-266, 2013.

[33] D. Li, W. Jiao, F. Yue, X. Xiang, and L. Pan, "Natural fractures and their effects on reservoir reconstruction in Lower Cambrian shale, southeast Chongqing, China," Energy Exploration \& Exploitation, vol. 33, no. 6, pp. 769-783, 2015.

[34] R. Marrett and S. E. Laubach, "Diagenetic controls on fracture permeability and sealing," International Journal of Rock Mechanics and Mining Sciences, vol. 34, no. 3-4, pp. 204.e1204.e11, 1997.

[35] O. Abiola and R. Mileva, "Diagenetic influence on fracture conductivity in tight shale and $\mathrm{CO} 2$ sequestration," Energy Procedia, vol. 63, pp. 5021-5031, 2014.

[36] L. Zeng, W. Lyu, J. Li et al., "Natural fractures and their influence on shale gas enrichment in Sichuan Basin, China," Journal of Natural Gas Science and Engineering, vol. 30, pp. 1-9, 2016.

[37] Y. Feng, W. Jiao, and S. Guo, "Controlling factors of fracture distribution of shale in Lower Cambrian Niutitang Formation in southeast Chongqing," Coal Geology \& Exploration, vol. 43, no. 6 , pp. $39-44,2015$. 
[38] J. Tremosa, H. Gailhanou, C. Chiaberge et al., "Effects of smectite dehydration and illitisation on overpressures in sedimentary basins: a coupled chemical and thermo-hydromechanical modelling approach," Marine and Petroleum Geology, vol. 111, pp. 166-178, 2020.

[39] D. Liu, C. Zhang, Z. Pan et al., "Natural fractures in carbonaterich tight oil reservoirs from the Permian Lucaogou Formation, southern Junggar Basin, NW China: insights from fluid inclusion microthermometry and isotopic geochemistry," Marine and Petroleum Geology, vol. 119, article 104500, 2020.

[40] W. Gao, J. Iqbal, D. Xu, H. Sui, and R. Hu, "Effect of brittle mineral size on hydraulic fracture propagation in shale gas reservoir," Geofluids, vol. 2019, Article ID 9147048, 14 pages, 2019.

[41] P. G. Meredith, "Fracture and failure of brittle polycrystals: an overview," in Deformation Processes in Minerals Ceramics \& Rocks, Springer, 1990.

[42] H. McQuillan, "Small-scale fracture density in asmari formation of southwest Iran and its relation to bed thickness and structural setting," AAPG Bulletin, vol. 12, pp. 2367-2385, 1973. 